\title{
CONTROL OF HEALTH SERVICES
}

A BROADSHEET "The Control of Health Services" issued by P' EP (Political and Economic Planning) emphasizes the need for an administrativo reorganization of the local public health services, and outlines various proposals which have been made with this object. From an administrativo standpoint, public health services are divided into thoso directly administered by the central government departments, those controlled by local authorities under such supervision and tho National Health Insurance Scheme. The central department primarily responsible for the public health services in England is the Ministry of Health, but the supervision of the school medical service is dolegated to the Board of Education. The Board of Control, which is the supervising body of the services for mental patients and mental defectives, is responsible to Parliament through the Minister of Health, as is tho Genoral Register Offico dealing with population statistics. Most of tho Minister's powers over public health services in Wales are exercised through the Welsh Board of Health, whilo in Scotland the Department of Health for Scotland performs much the samo functions as the Ministry of Health but controls the medical inspection of school children. The Medical Research Council is under a Committeo of the Privy Council, whilo the Factory Act, including its medical provisions, is ad. ministered by the Home Office. 'The National Health Insurance Joint Committeo co-ordinates the work of the Ministry of Health, tho Department of Jealth for Scotland, the Welsh IBoard of Health and tho Ministry of I,abour for Northern Ireland in connexion with National Health Insurance.

Wighty-three county boroughs in England and Wales exerciso all statutory health functions allocated to local government, but outside their territory these are distributed between 62 county councils, including the London County Council, 306 municipal boroughs, 575 urban districts, 476 rural districts, 28 metropolitan boroughs and the Corporation of the City of London. 'The 24 large Scottish burghs are virtually independent health authorities but except in Aberdeen, Dundee, Edinburgh and Glasgow are not concerned with the school medical services, while the 17l small burghs have fower public health functions in their own right than tho Fnglish district councils.

Administrativo boundaries are already hindering developments which are possible through modern transport in centralization of equipment, and aerial defence is making regional planning of health services more urgent. The criticism in the report on the Anti-Tuberculosis Service in Wales and Monmouth. shire could probably be applied to many areas in England. Financial stringency is not the only cause of failure to deal with overcrowding; failure of the counties to put pressuro on ineficient district councils and to carry through a review of thoir areas, nopotism, prejudice, individualism and a rofusal to spend money on communal services aro contributory causes. The Committeo on the Scottish Health Services in 1936 advocated that the Department of Health should be empowered to call on local nuthorities to submit schemes for the provision and maintenance of certain services for the ureas of two or more authorities and similar proposals rrore mado in the minority report of tho Royal Commission on Local Government in the Tyneside Area in 1937 as an alternative to an even more raclical proposal of the majority report for administration of specified health services by a regional authority.

Practically all these schemes, like that of tho British Medical Associntion, "A General Medieal Service for the Nation", propose an administrative division between tho environmental and the personal health services, the former being administered by local units and the latter by regional authorities over a wide area. 'The British Medical Association scheme proposed that councils with a population of less than 75,000 in rural and 100,000 in urban areas should leavo all their public health functions to a system of complete and comprehensivo local public health administration units. The plans of the Ministry of Health to meet an emergency as revealed in the House of Commons may ultimately lead to radical changes in the organization of the health services.

\section{MACROMOLECULES}

\begin{abstract}
IN a lecturo to tho Freiburger wissenschaftlicho 1 Gesellschaft (published by IIans Speyer Vering Hans Ferdinand Schulz, Freiburg im Breisgau), Prof. H. Staudinger roviews the naturo and importanco of macromolecules, which play such an important part in the chemistry of living tissues. These compounds possess many unexpected properties which cannot bo foreseen from a study of simpler substances.

A macromolecule is defined as one built up of not less than a thousand atoms bound together by primary valencies. At present no upper limit is known to the size of the molecule, but it is possible to group them into threads, plates and spheres. 'Tho simplest are high polymers derived from simple unsaturated compounds, for example, vinyl chlorido polymerizes to a product in which three thousand
\end{abstract}

simple molecules are combined by co-valencies and which is used for synthetic leather, tubing, etc. In this case the product is a complex mixture which can be partly resolved by fractionation into what are called polymerhomologues. Svedberg has shown that tho molecules of many proteins aro uniform but native celluloso can bo partly depolymerized into lower products with varying degrees of polymerization. Thus a polymerhomologous series of celluloses exists and the samo holds also for starch, glycogen, caout chouc and balata.

A method has been found of studying changes in physical properties of the products and of their solutions with change in degree of polymerization. Both homopolar and heteropolar combinations are known. Hydrocarbons like polystyrols may form sols 
with orgunic solvents but not with water, while the introduction of hydroxyl groups may reverso this effect. Again, the introduction of polar groups may result in hydrosol formation. By tho polymerization of acrylic acid, it is possible to build up a complete polymerhomologous series with degrees of polymerization ranging from 10 to 2,000 . Theso acids and their salts givo osmotic pressures which aro about one fifth of the theoretical values, and poly. valent anions may exert a similar buffering effect on the osmotic pressures of cations. The behaviour of albumens is particularly complicated, since both acid and basic radicals are present. The polyncrylic acids havo served as a model in unravelling theso complexities. The physical properties of linear or thread molecules depend on molecular length. It is convenient to group them into hemicolloids with length from $50 \mathrm{~A}$. to $250 \mathrm{~A}$., mesocolloids $(250-2,500 \mathrm{~A}$.) and eucolloids (above 2,500 A.) of which only the last-named group possesses typical macromolecular properties such as toughness, fibrous structure and the power of swelling. The viscosities of heteropolar thread molecules are complicated by swarming of the fibre-ions, which is affected by the presence of salts and acids.

Sinco macromolecules have the dimensions of colloid particles, any solutions that are formed are colloidal and may bo termed macrocolloidal to distinguish them from the molecular colloids or micelles of soaps and dyes, which aro very much less stable, since they do not involvo principal valencies. In somo cases macromolecules aro formed by true condensation, for example, through loss of water. It is necessary to be ablo to distinguish between macro. molecules and micelles. Particlo sizo in homopolar compounds can be determined from osmotic pressure and with the help of the ultracentrifuge. The study of acetylated products is of great importance, for if the degree of polymerization is unaltered by acety. lation the original compound must have been macromolecular since micelles could not withstand such drastic treatment. Unfortunately, this very simple principle is difficult in application since by-reactions may have a far-reaching effect.

Chemical investigation is rendered difficult by tho fact that the greater tho sizo of tho macromoleculo the smaller is the proportion of active reagent (water, oxygen, etc.) needed to bring about chemical change. Nativo caoutchouc contains thread molecules with a degreo of polymerization of two to three thousand and swells greatly in water. On exposure to air the threads becomo linked at few points only by oxygen bridges so that an insolublo product results with limited swelling power, but tho amount of oxygen absorbed is too small to determine. Nitrogen has no such action. Again, synthetic polystyrol threads can be linked at long intervals by using a minute amount of divinylbenzene so that a network is obtained which can be solvated but not dissolved. In somo similar fashion, albumens can pass from a soluble form with unlimited swelling power to an insolublo form with limited swelling. Again, minute chemical changes such as methylation of terminal groups alone of a very long chain may infuence chemical character; thus the dimethylether of polyoxymethyleno is stable to sodium hydroxide. These facts are of great importance in the study of hormones and vitamins, which may bo regarded not as mere catalysts but as reagents capablo of reacting in minuto quantities on macromolcculo: to produce far reaching effects.

\section{SCIENCE NEWS A CENTURY AGO}

The August Meteors seen at Breslau

Ox August 14, 1839, the German astronomer Boguslawski wrote an account of his observations at Breslau of the August meteors, popularly lnown as "the tears of St. Inwrence"; the account being published in the Prussian State Gazette. "l'ho sky," ho said, "has been again particularly propitious for observing another fall of stars. On many days and nights preceding the loth tho heavens have been so covered that wo could not observe when the uncom. monly frequent fall of stars commenced. On Aug. 10, horrever, our hopes of secing the phenomenn increased owing to tho clearness of tho weather. . . It was not, however, sufficient to count the numbers that fell; it was desirablo also to measuro tho time of their appearance, and of the continuance of their fall, according to Franzmann's instrument, which beats thirds of seconds, and moreover to ascertain their relative height and apparent course in the heavens and all theso observations could commence only at 26 minutes past 9 when all tho observers, 15 in number, wero assembled, occupying six windors of the observatory. Four gentlemen took care to observe and register the times of each appearance, according to two clocks. Till 14 minutes past 3, when dawn put a stop to the observations, they noticed 1008 falling stars, not including numbers which must havo been overlooked because the numbers of observers was insufficient". Other meteors were seen on August 11 and 12 and "therefore," wrote I3oguslawshi, "the annual periodical return of an uncommon fall of stars towards the 10th of August is once moro confirmed".

\section{Steam Applied to Land Drainage}

Ox August 17, 1839, the Nechanic and Chemist said : "This drainago of land by steam power has been extensively adopted in the fens of I,incolnshiro, Cambridgeshire, and Bedfordshire and with immenso advantage. An engino of forty horso power, and scoop wheel for draining, and requisito buildings, costs about $£ 4,000$, and is capablo of draining about 4,000 acres of land. In many places in the fens, land has been purchased at from $£ 10$ to $£ 12$ per acre, which has been so improved by drainago as to be worth $£ 60$ or $£ 70$ per acro". One of the largest districts drained was Deeping Fen near Spalding containing 25,000 acres, where thero wero pumping engines of 80 horse-power and 60 horse-power. Littleport Fen, near Ely of about 28,000 was drained by two engines whereas formerly there were 7.5 winddriven pumps. Soham Mere, near Cambridge, forming a lako of 1,600 acres was drained by $\Omega 40$ horse-power engine.

\section{UNIVERSITY EVENTS}

Casibridge.-J. C. Colbeck has been elected John Lucas Wralker student.

A. F. Iluxley, of Trinity College, has been elected to the Michael Foster studentship in physiology.

Dr. K. C. Dixon, of King's College, has been ararded the E. G. Fenrnsides scholarship.

Oxrond.-Dr. I. A. Woodward, Lincoln College, has been appointed fellow and tutor of Jesus Collego in chemistry in succession to the late H. J. George. 